\title{
GEOLOGY OF THE HEAVY OIL IN NORTH BULGARIA \\ - PAST, PRESENT AND FUTURE USE
}

DOI: http://dx.doi.org/10.18509/GBP.2016.25

UDC: 552.98.04(497.2)

\author{
Assoc. Prof. Dr. Nikola Botoucharov \\ Sofia University “St. Kliment Ohridski”, Bulgaria
}

\begin{abstract}
Nowadays we are gradually running out of sedimentary basins to explore and the reserves of conventional oil which can be produced easily are limited. This is the reason why many of the petroleum companies look for other types of resources. Moreover, we are increasingly investing in unconventional hydrocarbons including heavy oil.

The objects in this research are the heavy oil discoveries in North Bulgaria. The main tasks include geological characterization of the discovered heavy hydrocarbons, production and probable future of this natural resource. However, industrial and semiindustrial reserves of heavy and viscous crude oil are found only in carbonates of the Lower Cretaceous Kaspichan Formation in Tjulenovo oilfield and Gigen accumulation. Although, the accumulations are in considerable distance from one another they show a number of common reservoir and chemical composition features.

The eroded and fractured reservoirs are located relatively in shallow depths and represented by permeable carbonate rocks of Kaspichan Formation - mainly dolomites and dolomitic limestones. The best reservoir horizons are primarily located in medium grained and crystallinity dolomites. They are characterized by maximum effective porosity of $15-20 \%$ and average permeability of $500 \mathrm{mD}$ in Tjulenovo. The other permeable carbonate types are defined by significantly lower qualities with open porosity in the range of $1.1-7.3 \%$ for limestones in Gigen. The reservoirs are three types with domination of fractured-porous-cavernous over porous and fractured-porous types.

The heavy oil in both accumulations is very viscous and with Naphtene-Aromatics chemical composition. Except for the fractional composition their physical indicators are similar as well. The past, present and presumably future use of Tjulenovo oil is for steamboiler fuel, water-proofing seals, technical bitumen and grease. Although, the Gigen heavy oil has never been exploited it can be also useful. The natural resource was experimentally processed by oxidation to obtain all brands of technical and special bitumen. The problem with Gigen heavy hydrocarbons is the economic profitability and need for enhanced oil recovery. The probable reserves of about $0.5 \times 10^{6} \mathrm{t}$ and present price of crude oil make production extremely questionable at the moment.
\end{abstract}

Keywords: North Bulgaria, heavy oil, Kaspichan Formation, permeable carbonates, enhanced oil recovery

\section{INTRODUCTION}

Industrial and semi-industrial reserves of heavy and extra heavy oil are discovered only in carbonates of the Lower Cretaceous (Kaspichan Formation) in Tjulenovo oil field and Gigen accumulation, both in the Moesian Platform (Fig. 1). 


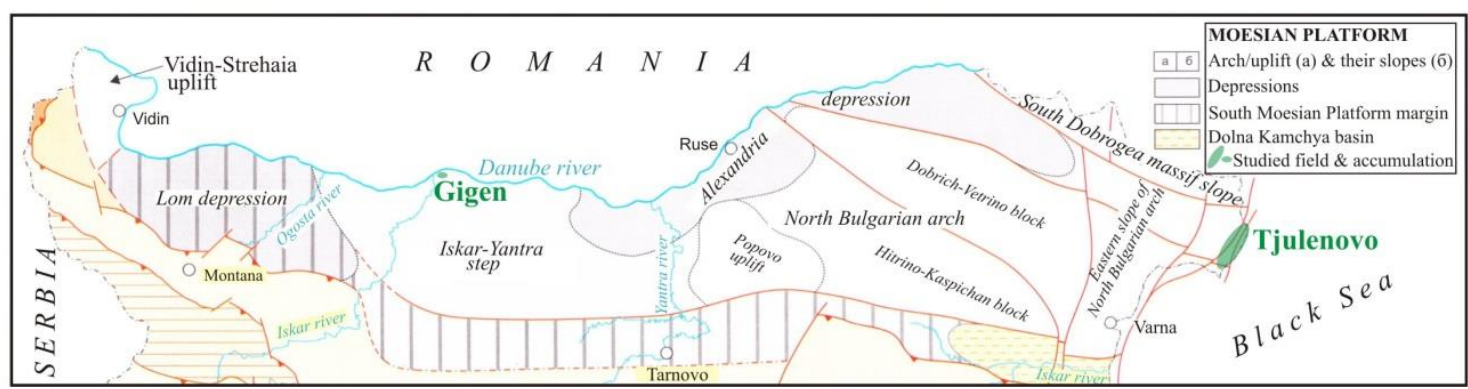

Figure 1. Tectonic map of the North Bulgaria with location of heavy oil accumulation (after [1]).

Both accumulations were found in 10 years period, respectively in 1951 for Tjulenovo and 1961 for Gigen. Tectonic location of Tjulenovo and Gigen in North Bulgaria shows that both accumulations are in the Moesian Platform, but in different subunits. Although, both hydrocarbon deposits are quite distant from one another they are similar. In addition to common features such as relatively small depth, lithology of the reservoir, chemical composition of heavy oil and the age of the natural reservoir, there are number of differences.

The main purpose of this research is a comprehensive review and analysis of specific geological and geochemical features of hydrocarbons in the study area to show diversity and application of heavy oil in Tjulenovo field and Gigen accumulation. Therefore, the essential tasks include geological and reservoir characterization of the discovered hydrocarbons, production, contemporary use and probable future of this natural resource.

\section{GEOLOGY OF THE STUDY AREA}

Tectonic division of the Moesian Platform is mainly based on regional structural behaviour of Cretaceous, Jurassic and Triassic sediments. In North East Bulgaria the Moesian platform, according Jurassic-Lower Cretaceous sediments, is divided into three major parts. The eastern part is known as the Eastern slope of North Bulgarian arch (Fig. $1)$.

Tjulenovo field is located in the Shabla-Bulgarevo graben area of the Eastern slope of North Bulgarian arch (Fig. 2). The Eastern slope of North Bulgarian arch occupies the entire territory east of Venelin-Tolbouhin dislocation and south of the South Dobrogea massif slope. The area most characteristic feature is pronounced block structuring by Paleozoic and Triassic rocks. Shabla-Bulgarevo graben area has sub-meridional direction and is characterized by thick about $2500 \mathrm{~m}$ sequence with mainly Triassic sediments. Tjulenovo horst (in green), east of St. Nikola fault, can be easily delineated considering the top of the Valanginian and younger (especially Oligocene) sediments (Fig. 2). The eastern parts of the horst structurally extend to the Black Sea. The Tjulenovo oil field is characterized by a complicated block structure with 33 north-south and 13 west-east directed normal faults, broken into 32 or 36 blocks [3, 4]. The blocks are divided into three zones - north (Shabla), Central (Tjulenovo) and southern (Nanevo). 


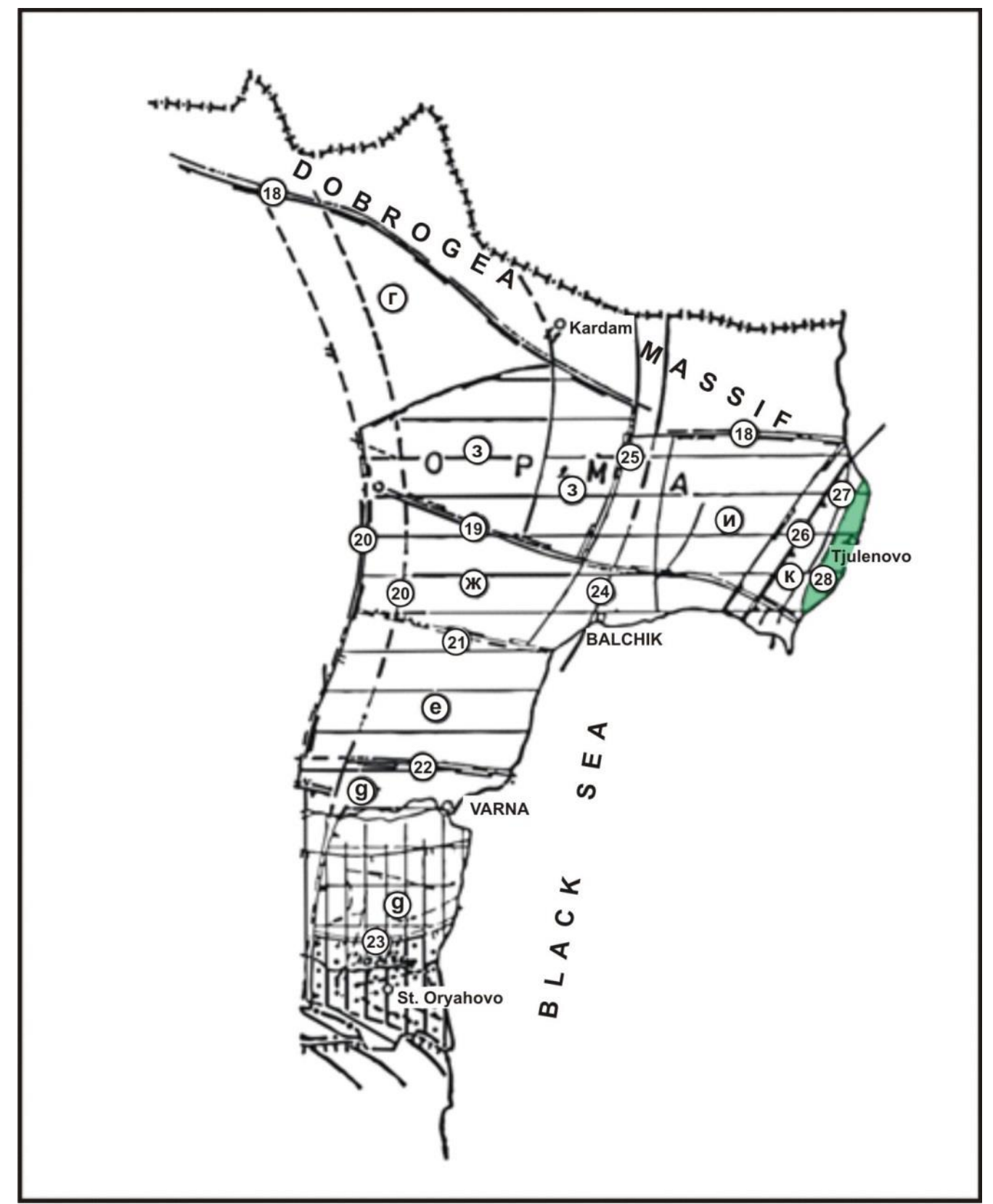

Figure 2. Main tectonic units in the Eastern slope of North Bulgarian arch (after [2]).

Tectonic units: г-Generaltoshevo saddle; д-Avren step; е-Kichevo block; ж-Balchik block; и-Vranino block; к- Shabla-Bulgarevo graben.

Faults: 18-Silistra-Belgun; 19-Bezvoditsa-Selchen; 20-Venelin- Tolbouhin; 21-Batovo; 22-Kichevo; $23-$ Bliznatsi; 24-Balchik; 25-Trigortsi; 26-Rakovski-Gorun; 27-Bulgarevo; 28-St. Nikola.

Gigen accumulation is located in Gigen-Korabiyska rise of Iskar-Yantra step (Fig. 1). The Iskar-Yantra-step is a single morphostructural zone in the Upper Jurassic-Lower Cretaceous structural floor [5]. The Triassic structural plan is much more differentiated. The extra heavy oil deposits are localized in Gigen structure of extensive Brest-DabovanGigen block.

The southern part of Gigen-Korabiyska rise is in the highest contemporary hypsometric level compared to adjacent zones [5]. There is notable monoclonal elevation of the Triassic and Jurassic-Lower Cretaceous rocks here and to the north of Danube River. 
Upper Jurassic-Lower Cretaceous (Valanginian) sedimentary complex in the study area shows the following lithostratigraphic units: Dobrich Formation, Yavorets Formation, Provadia Formation, Chernookovo Formation, Drinovo Formation and Kaspichan Formation (Fig. 3).

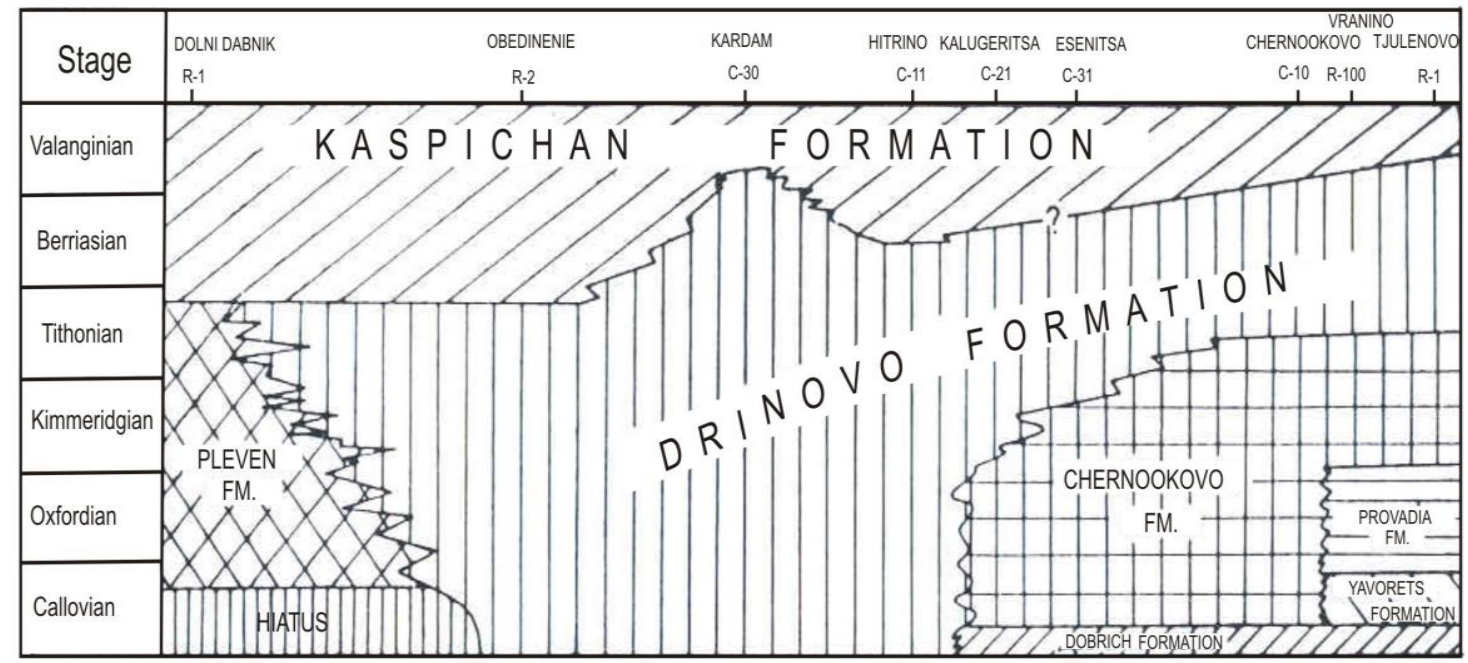

Figure 3. Spatial-temporal relationships of Upper Jurassic-Lower Cretaceous lithostratigraphic units along profile line R-1 Dolni Dabnik - R-1 Tjulenovo in North Bulgaria (compiled after [6], [7]).

The Formations are in complex spatial relationships with each other. Their boundaries are mostly clear, but there are also lateral transitions between lithostratigraphic units. They result from the development of the sea basin inherited from Callovian and continued its development during Late Jurassic and Early Cretaceous in entire North Bulgaria. During that period there are areas with relatively different sedimentation regime. Their existence determined subequatorial facial zoning and various facial environments. As a consequence of widespread and continuous sedimentation the accumulated deposits have substantial overall thickness that is growing rapidly from north to south.

Kaspichan Formation is main object of this study, because its carbonates are reservoir for heavy oil in Tulenovo and extra heavy accumulation in Gigen. Kaspichan Formation [8] has a wide distribution in Northeastern Bulgaria and covers southeastern part of the Moesian Platform. The Formation continues to the west, but with larger chronostratigraphic range and in many cases thicker (Fig. 3). There are carbonate rocks of varied composition: dolomites, calcareous dolomites, limestones, dolomitic limestones and rare single layers of marls and clays in bore holes C-30 Kardam and C-10 Chernookovo. Usually dolomites and dolomitic limestones build base and secondary levels of Kaspichan Formation. Stratigraphic range varies and is connected primarily with Cretaceous stages (Berriasian, Valanginian and lower Hauterivian substage partly). Its thickness is from 500 to $900 \mathrm{~m}$.

STRUCTURAL, RESERVOIR, PHYSICAL AND CHEMICAL FEATURES OF HEAVY OIL IN TJULENOVO FIELD AND IN GIGEN ACCUMULATION

The Tjulenovo trap is structural (anticline), broken into blocks with tectonic and stratigraphic features. The trap and oil deposits are formed in Neogene time. It is a 
massive type with heavy oil and initial gas part. The height of oil-gas deposits varied from 60 meters in the northern part of the field up to 38 meters in the central part.

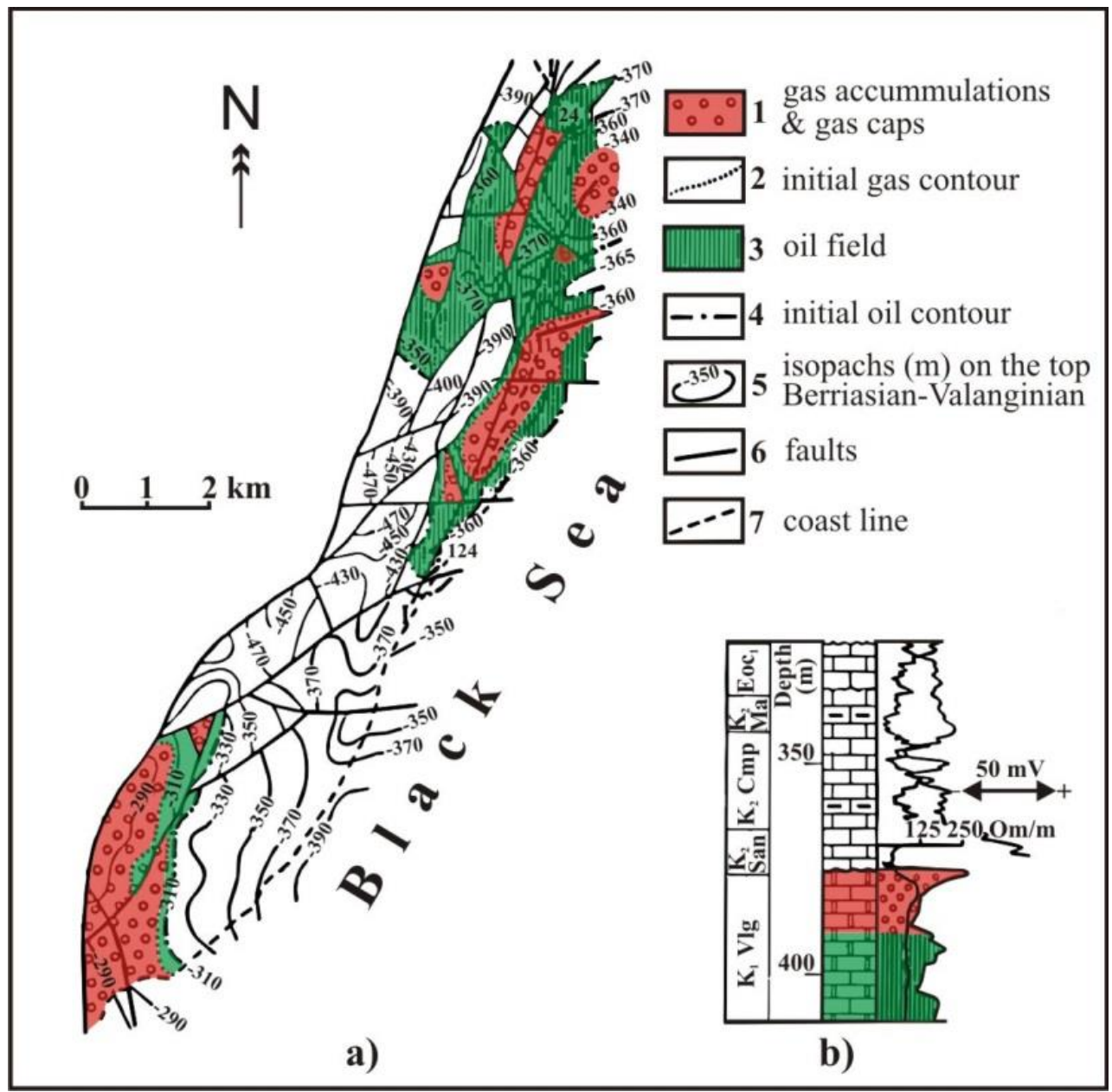

Figure 4. Tjulenovo field with a) Structural map showing top of the productive horizon; b) Lithological section with logs and hydrocarbons [9].

The reservoir is made of irregularly alternating fractured, cavernous limestones and dolomites in the upper part of Valanginian (Kaspichan Formation) at a depth of 350-400 $\mathrm{m}$. The reservoir is a complex one porous-fractured-cavernous. The higher reservoir properties have middle crystalinne dolomites with effective porosity $15-20 \%$ and average permeability of $500 \mathrm{mD}$.

Oil from Tjulenovo field is characterized by high density of $0.938 \mathrm{~g} / \mathrm{cm}^{3}$ and API gravity 19.4 (heavy oil), viscous, low sulfur, low paraffin, high resin and asphaltene content. Fractional oil composition includes light fractions (4\%), kerosene (13\%), oil (8\%) and oil fuel $(75 \%)$. boiling point is $+126^{\circ} \mathrm{C}$ and freezing temperature is $-24^{\circ} \mathrm{C}$.

Low-amplitude Gigen structure is formed in top Valanginian part of the section. The trap is with an amplitude of $20-30 \mathrm{~m}$ and depth is approximately $800 \mathrm{~m}$. The extra heavy oil is accumulated in Valanginian dolomites and limestones in the upper parts of Kaspichan Formation. The height of accumulation (trapped oil) is about 18 meters. The rocks are intensely fractured and water-washed forming paleokarst with voids - pores, fractures, vugs and caverns. Investigations of limestones in boreholes R-2 and R-3 Gigen show 
changes in open porosity of 1.1 to $7.3 \%$ or $3 \%$ on average. The reservoir is complex. There are fractured-cavernous-porous, porous and rarely fractured-porous rocks.

Gigen heavy oil is with density $0.9889 \mathrm{~g} / \mathrm{cm}^{3}$ and API gravity of 11.6 . The chemical composition is dominated by the high molecular weight aromatic (about 37\%) and resin - asphaltene components (about 30\%). The main physical and chemical indicators show high viscosity even at $100^{\circ} \mathrm{C}$, sulfur 0.98 wt. $\%$, pour point $+12^{\circ} \mathrm{C}$, paraffins 0.5 wt. $\%$, asphaltenes $8.07 \mathrm{wt} . \%$, resins $88.4 \mathrm{wt}$. \%. These data clearly suggest that the oil is very heavy, low sulfur, high resins, practically without paraffins, highly viscous, without gasoline-kerosene fractions.

\section{DISCUSSION ON THE PROCESSING AND USE OF HEAVY OIL IN TJULENOVO AND GIGEN}

In the era of the energy and the likely end to the "oil age" interesting issue is the extraction and use of heavy oil from Tjulenovo field and Gigen accumulation. The ability for a prediction of the properties of bitumen in the early prospecting and exploration will lead the exploitation to the right direction and determine their application. The developed exploitation methods of heavy oil and unconventional hydrocarbon resources are very diverse, but the most economically advantageous to extract bitumen is limited to the traditional "destructive distillation." This is a relatively simple and easy to use method using hot water or steam.

The industrial production of Tjulenovo oil began more than 50 years ago in September 1954. The field has been developed rapidly, creating a dense network of wells. More than 700 boreholes are drilled until now and the field is in the final stage of operation. Due to the nature of the reservoir, the flow of oil in the individual wells was ranging widely, with some amounted to $320 \mathrm{t} /$ day. Since the field is in the final (exhausting) stage of operation, then over $98 \%$ of the recoverable reserves are already produced. The production is over $3.2 \mathrm{mln}$. t. of oil until now. The application and technical use of the heavy oil, depending on its chemical composition and so far is limited to the steam-boiler fuel, water-proofing seals, lubricating oil, technical bitumen and grease.

Tjulenovo heavy oil belongs to the altered types of oil as the main reason is the secondary migration and shallow depth conditions with oxidation and biochemical processes. It does not contain any recognizable n-alkanes, indicating that is medium to highly biodegraded and water washed. As Tjulenovo oil is discovered in small depth (350-400 $\mathrm{m})$ it is almost with normal pressure, but with a slightly elevated anomalous temperature of $37-38^{\circ} \mathrm{C}$. This is proof that oil has migrated from deeper levels, as has retained some of its original heat. Progressive water saturation has increased since 1964 and current water amount in production is above $99 \%$.

Gigen heavy oil is completely degassed and objects of destruction under the influence of formation water oxidation effect and bacteria. Therefore, oil is "dead" and completely lacking of petroleum gas. The hydrocarbons in the accumulation are highly viscous with consistence and chemical composition characteristics for transition between oil and asphalt. Gigen heavy oil is not in operation and has not been exploited, because the small probable reserves (about $0.5 \times 10^{6}$ tons) and the difficult conditions of production.

A few years after discovery of Gigen accumulation in 1961 there were several proposed techniques for hydrocarbon processing [10]. The most important are 1) Oxidation for obtaining of bitumen; 2) Processing for heavy types of oil; 3) Hydrogenation. 
Originally it was believed that the oxidation is the most effective for the preparation of different brands of bitumen for technical use. Most suitable for the production of bitumen are oil products such as the goudron (vacuum residue or asphalt) from residues and waste from other industries. Very relevant are those with resin - asphaltene character like hydrocarbons from Gigen. Experimental in the oxidation of such materials primarily undergoing processes of conversion of available resins to asphaltenes, and the process of formation of resins from hydrocarbons play a subordinate role. An advantage is that high molecular weight oil turns into resins faster than low molecular weight constituents. Gigen oil and its products differ from Tjulenovo goudron mainly to the significantly higher content of asphaltenes [10]. On the other hand the content of oils and resins is pretty close. They are also similar in the physico-chemical parameters (melting point, viscosity, density, etc.). Good laboratory results from the oxidation of Tjulenovo goudron for production of bitumen and insignificant amount fractions to $360^{\circ} \mathrm{C}$ at $4 \mathrm{~mm}$ mercury column are very optimistic for future technical use of heavy oils in Bulgaria. Therefore, it is reasonable to expect production of various brands of bitumen by oxidation directly on Gigen oil.

The exploitation of Gigen heavy oil from a depth of 800-900 $\mathrm{m}$ is possible by pumping back hot water or steam (injection method). Its application to improve the viscosity of the hydrocarbons is the most efficient and relatively inexpensive for the present conditions. Alternatively aeration of oil (decreasing of density) with air through a compressor is also good option, since no concomitant petroleum gas in Gigen accumulation. The problem with heavy hydrocarbons there is the economic profitability and need for enhanced oil recovery. The probable reserves of about $0.5 \times 10^{6} \mathrm{t}$ and present price of crude oil make production extremely questionable at the moment.

\section{REFERENCES}

[1] Zagorchev, I., Dabovski, C. \& Nikolov, T. (Eds.). Geology of Bulgaria. Volume II. Mesozoic geology. S., Acad. Publishing house „Prof. Marin Drinov”, 766 p., 2009. (in Bulgarian).

[2] Bokov, P., Chemberski, H. (Eds.). Geological prerequisites for oil and gas of Northeastern Bulgaria. S., Technika, 332 p., 1987. (in Bulgarian).

[3] Yovchev, Y., Balukhovsky, N. The oil and gas prospective regions of the PR Bulgaria and their geologic structure. S., Technika, 79-88, 1961. (in Bulgarian).

[4] Deshev, E. Geology and exploration of oil and gas fields. S., Technika, 306 p., 1991. (in Bulgarian).

[5] Atanasov, A., Bokov, P. (Eds.). Structural and tectonic features. In: Geology and oil and gas perspectives of the Moesian Platform in Central North Bulgaria, 78-136, 1983. (in Bulgarian).

[6] Atanasov, A., Bokov, P. (Eds.). Introduction in the stratigraphy of the sediments from the Mesozoic erathem. In: Geology and oil and gas perspectives of the Moesian Platform in Central North Bulgaria, 10-44, 1983. (in Bulgarian).

[7] Nikolova, L., Sapunov, I. Upper Jurassic-Lower Certaceous dolomitic unit in eastern part of the Moesian Platform and its place in the official lithostratigraphic scheme. Rev. of Bul. Geol. Soc., 46, 1, 78-83, 1985. (in Bulgarian). 
[8] Nikolov, T. Stratigraphy of the Lower Cretaceous in part of Northeastern Bulgaria. Bull. of Geol. Inst., Stratigraphy and lithology series, 18, 31-71, 1969. (in Bulgarian).

[9] Kalinko, M. (Eds.). Oil and gas fields. In: Geology and Oil-gas Bearing of North Bulgaria. M., Nedra, 87-104, 1976. (in Russian).

[10] Gerasimov, M., Dimitrova, R. Obtaining bitumen from Gigen oil. Chemistry and Industry, 6, 214-218, 1964. (in Bulgarian). 